\title{
ÜLDKÜSIMUSE VORM JA FUNKTSIOONID LÄBI NELJA SAJANDI JA KUUE TEKSTILIIGI ${ }^{1}$
}

\author{
TIIT HENNOSTE, HELLE METSLANG, \\ KÜLLI HABICHT, ANNI JÜRINE, \\ KIRSI LAANESOO, DAVID OGREN
}

Annotatsioon. Artikkel käsitleb üldküsimuse vormivahendeid ja funktsioone ning vormi, funktsiooni ja tekstiliigi seoseid kirjalikus eesti keeles: XVII-XVIII sajandi usulistes ja õpetlikes tekstides ning tänapäeva ilukirjandus- ja ajakirjandustekstides, netikommentaarides ja -dialoogides.

Üldküsimuse põhiline funktsioon on oma arusaamale kinnituse küsimise soov (oletus- ja kahtlusküsimus), mida täidab üle poole küsimustest. Infosoov (baasküsimus) annab kõigis tekstiliikides alla 1/3 küsimustest, lisaks esinevad nn kooliküsimused, direktiivid ja retoorilised küsimused. Üldküsimuse vormivahendid jagame primaarseteks (küsimarkerid ja sõnajärg) ja sekundaarseteks (küsimust markeerivad sidesõnad (ja mõned muud sidendid) ning episteemilised üldlaiendid). Infosoovi vormistajana eelistatakse tänapäeva tekstides lausealgulisi küsipartikleid ja inversiooni ning oletusküsimuse vormistamisel lauselõpulisi küsimarkereid, sekundaarseid vormivahendeid või markeerimata lauseid. Küsimuse peamine funktsioon ning funktsioonide ja vahendite seos ei olene tekstide sünniajast, tekstiliikidest ega suhtluse tegelikkusest või fiktsionaalsusest. Vahendite eelistust ei muuda ka tekstide suhe normingutega ega erinevad suhted kontaktkeeltega.

Võtmesõnad: kirjakeel, uus meedia, üldküsimus, küsimuse funktsioonid, eesti keel

1 Kirjutise valmimist on toetanud projekt EKKM14-340 „Eesti keele akadeemiline grammatika“ ning Euroopa Liit Euroopa Regionaalarengu Fondi kaudu (Eestiuuringute tippkeskus); see on seotud Eesti Haridus- ja Teadusministeeriumi uurimisprojektiga PUT475 „Kirjakeele morfosüntaksi varieerumise integreeritud mudel: pilootuuring eesti keele näitel“". 


\section{Sissejuhatus}

Artiklis käsitleme üldküsimuse vormivahendeid ja funktsioone ning nende seoseid kirjalikus eesti keeles läbi nelja sajandi ja kuue tekstiliigi. Analüüsime seda, milliseid vormivahendeid on üldküsimuse moodustamiseks kasutatud, milliseid funktsioone täidavad üldküsimused eri tekstiliikides ja kuidas seostuvad omavahel küsimuse vorm ja funktsioonid. Lõpuks peatume ka küsimuste vormi ja funktsiooni varieerumise võimalikul seosel küsimuste tegelikkuse ja fiktsionaalsuse, kirjakeele normingute ning kontaktkeeltega.

Üldküsimus - küsimuste liik, mis eeldab kas jaatavat või eitavat vastust - on olnud viimasel ajal populaarne uurimisobjekt nii rahvusvahelises kui ka eesti lingvistikas (nt Romero, Han 2004; Reese 2007; Miestamo 2009; Stivers, Enfield 2010; Heritage 2012; Metslang jt 2011, 2015). Üheks põhjuseks on asjaolu, et sellel on eri keeltes mitmeid vormivariante, mis seostuvad eri funktsioonidega. Küsimuste vormi ja funktsioonide seoseid on empiirilise materjali põhjal uuritud ennekõike suulises keeles (vt nt Nijmegeni Max Plancki Instituudi projektide kohta Enfield jt 2010; Dingemanse jt 2014). Kirjaliku keele kohta leidub vaid üksikuid uurimusi (nt Hyland 2002; Marley 2002), enamasti on piirdutud tähelepanekutega grammatikaülevaadetes. Eesti keele kohta on olemas sissevaated suuliste küsimuste vormi ja funktsioonidesse (Hennoste jt 2013) ning käsitlus kirjalike küsimuste vormivahendite kasutussageduse ja kasutuse muutumise kohta (Metslang jt 2011). Samas puuduvad kirjaliku eesti keele kohta tekstikorpustele toetuvad funktsioonide ja vormi seoste uuringud. Muude vaatenurkade kõrval ka funktsioone arvestav küsilausete käsitlus pärineb korpuste-eelsest ajast (Metslang 1981).

\section{2. Üldküsimuse vorm ja funktsioonid}

Siinses artiklis jagame üldküsimuse vormivahendid kahte rühma (vt tabel 1). Esimese rühma moodustavad primaarsed vormivahendid, mille hulka kuuluvad küsimarkerid ja küsimusi vormistavad sõnajärjed. Küsimarkerid jaotame kolmeks: lausealgulised küsipartiklid (kas, ega, eks jt), lauselõpulised küsipartiklid (või, vä) ja küsijätkud (eks ole, kas pole, jah, ah, mis jms). Sõnajärjega vormistatud küsimused jagunevad samuti kolmeks. Esimene võte on inversioon, milles verbi ja tüüpiliselt lause alguses paikneva lauseliikme (aluse, valdajamääruse vm) kohad 
on vahetatud (Oled sa viimasel ajal Juhanit näinud?). Teine sõnajärjega seotud võimalus on verbi paiknemine lause alguses ilma inversioonita, sest puudub lauseliige, mis võiks verbiga kohad vahetada (Oled õhtul kodus?), kolmas viis on verbi paigutamine lause lõppu (Sul jalgratas on?) (Metslang 1981: 26-28). Tõenäoliselt on sõnajärjenihkega malli kujunemises oma roll ka verbi fokuseerimisel: fookuse positsiooni, lause lõppu või algusse (vt Lindström 2016) paigutub üldküsimuse sisuline kese, finiitverb.

Teise rühma kuuluvad sekundaarsed vormivahendid, mis võivad küsimusele viidata, kuid ei ole otseselt küsivahendid (vt Metslang jt 2014, 2015). Siia kuuluvad küsivust markeerivad või mõjutavad lausealgulised sidendid (aga, ja, nii et, et kas, et, või, nt Ja ta oli sellega nõus?) ning episteemilised üldlaiendid (äkki, viimaks, ju, siis, ehk jms, nt $\ddot{A k k i}$ ta on nõus?). Samuti loeme küsimusteks küsimärgiga lõppevad väitlaused (nende all ka lausefragmendid ja fraasid), milles muid küsivaid vormivahendeid ei leidu (Sa oled õhtul kodus? Täna kell kuus?), kuivõrd küsimärk on kirjutatud keeles ühemõtteline küsimuse vormistamise vahend.

Konkreetses lauses võib esineda nii primaarne kui ka sekundaarne vormivahend, nii üks vahend kui ka mitme eri vahendi kombinatsioon (nt sidesõna ja sõnajärg: Ja on ta nõus?; lausealguline küsipartikkel ja episteemiline üldlaiend: Kas sa oskad $\boldsymbol{e h k}$ ise midagi küsida? (ILU)).

Tabel 1. Artiklis käsitletud üldküsimuse vormivahendite tüübid

\begin{tabular}{|l|l|l|}
\hline \multirow{4}{*}{$\begin{array}{l}\text { Primaarsed } \\
\text { vormivahendid }\end{array}$} & \multirow{2}{*}{$\begin{array}{l}\text { Küsi- } \\
\text { markerid }\end{array}$} & Lausealgulised küsipartiklid (alguspartiklid) \\
\cline { 3 - 3 } & \multirow{2}{*}{ Sõnajärg } & Lauselõpulised küsipartiklid (lõpupartiklid) \\
\cline { 3 - 3 } & & Lauselõpulised küsijätkud \\
\cline { 3 - 3 } & Inversioon \\
\cline { 3 - 3 } & Verb lause algul \\
\hline \multirow{2}{*}{$\begin{array}{l}\text { Sekundaarsed } \\
\text { vormivahendid }\end{array}$} & Verb lause lõpus \\
\hline Väitlause & Sidendid \\
& Episteemilised üldlaiendid \\
\hline
\end{tabular}

Uurimustes on esile toodud erinevaid üldküsimuste funktsioone. Siinses käsitluses lähtume Tartu Ülikooli eesti kirjakeele morfosüntaktilise varieerumise töörühma Kimovar (http://www.kimovar.ut.ee/) tüpoloogiast, mis toetub Nijmegeni Max Plancki psühholingvistika instituudi töörühma käsitluste eeskujul arendatud eesti suuliste küsimuste funktsioonide 
tüpoloogiale (vt Stivers, Enfield 2010; Hennoste jt 2013: 8-10). Selle tüübistiku kategooriad on identifitseeritud tegelike tekstide kvalitatiivse analüüsi alusel. Kategooriad ei moodusta suletud süsteemi, vaid avatud loendi, millesse kuulub ka kategooria „Muu“. Sellesse paigutatakse juhtumid, mis ei mahu olemasolevatesse kategooriatesse. Me ei esita siinkohal kogu funktsioonide tüübistikku, vaid üksnes analüüsi käigus uurimismaterjalist leitud tüübid, mida artiklis käsitletakse (vt tabel 2). ${ }^{2}$

Tabel 2. Artiklis käsitletud üldküsimuse funktsioonide tüübid

\begin{tabular}{|l|l|l|}
\hline \multirow{2}{*}{ Pärisküsimus } & \multicolumn{2}{|l|}{ Infosoov } \\
\cline { 2 - 3 } & \multirow{2}{*}{ Kinnituse soov } & Oletusküsimus \\
\cline { 2 - 3 } Kooliküsimus & Kahtlusküsimus \\
\cline { 2 - 3 } & Infosoov & Oletusküsimus \\
\cline { 2 - 2 } & Kinnituse soov & Kahtlusküsimus \\
\hline Direktiiv & \multicolumn{2}{|l}{} \\
\hline Retooriline küsimus &
\end{tabular}

Esimese rühma moodustavad nn pärisküsimused, mille puhul küsija on vähemteadja või mitteteadja positsioonis ning soovib täita lünka oma teadmistes. Need küsimused jagunevad kaheks: infosoov, milles küsija ei paku ise võimalikku vastust (Kas sul kodus peeti on?), ja kinnituse soov, milles küsija pakub oma arvamuse, arusaama vms, oodates sellele kinnitust. Kinnituse soov jaguneb kaheks alltüübiks. Oletusküsimuse korral langeb eeldatav kinnitus eituse-jaatuse poolest küsilause vormiga kokku (Nii et päike ei läinudki looja? - Ei.). Kahtlusküsimuse korral on oodatav kinnitus eituse-jaatuse poolest küsilause vormile vastupidine (Kas ta viitsib seda tööd teha? - Ei.).

Teise rühma moodustavad nn kooliküsimused, mille puhul küsija on tegelikult teadja, kes kontrollib vastaja teadmisi. Sellistele, siinses materjalis vaid vanades usutekstides kasutust leidnud küsimustele on tekstis enamasti lisatud ka oodatav vastus, nt Salgkat sinna erra sedda Kurrati? Ja. Entsagest du dem Teuffel? Ja. (Stahl 1632). Ka need jagame kolmeks all-liigiks samal viisil nagu pärisküsimused. Kolmanda rühma moodustavad küsivormis direktiivid (Tuled ehk kaasa?). Neljas rühm on

2 Omaette teemaks on eitavas vormis üldküsimuste eripära, mis jääb siinsest artiklist välja (vt nt Metslang 1981: 35-36; Quirk jt 1985: 808-810). 
retoorilised küsimused, millega esitatakse seisukohti, väiteid jms ning mis tavaliselt ei oota partneri reageeringut (Kas mina ei olegi perekonnaliige?).

Küsimuste ja väidete paigutumist küsivuse-väitvuse skaalal võib näha kontiinuumina, mille ühes otsas on väitlausega vormistuv otsene väide ja teises otsas retooriline küsimus, mis on oma jaatavale või eitavale vormile sisult vastupidine väide.

1) Väide: Mari on tark laps (reaktsiooniks võib olla nõustumine jaatavas vormis väitega);

2) oletusküsimus: Mari on tark laps? (ootab kinnitust küsija hinnangul tõenäolisemale jaatavale vastusele: Mari on tark laps.);

3) infosoov: Kas Mari on tark laps? (ootab jaatavat või eitavat vastust, esitamata kumbagi tõenäolisemana);

4) kahtlusküsimus: Kas Mari ikka on tark laps? (ootab kinnitust küsija hinnangul tõenäolisemale eitavale vastusele: Mari ei ole tark laps.);

5) retooriline küsimus: Kas meie Mari on see kõige targem laps maailmas? (väidab, et ei ole; reaktsiooniks võib olla nõustumine eitavavormilise väitega).

Oletusküsimus jääb seega väite ja infosoovi vahele, kahtlusküsimus infosoovi ja retoorilise küsimuse vahele.

\section{Materjal ja meetod}

Uuritavad tekstid kuuluvad kuude ajaga piiritletud liiki: 1) XVIIXVIII sajandi usulised tekstid, 2) XVIII sajandi õpetlikud tekstid, 3) XXXXI sajandi ilukirjandustekstid, 4) XX-XXI sajandi ajakirjandustekstid, 5) XXI sajandi netikommentaarid ja 6) XXI sajandi netidialoogid.

XVII-XVIII sajandi tekstidest on Tartu Ülikooli vana kirjakeele korpusest uurimiseks valitud vaimulik kirjandus (jutlused, kirikuraamatud, piiblitõlked) ja XVIII sajandi õpetlik jutukirjandus, mis sisaldab tõlkemõjulisi poolilmalikke moraalset ja tervislikku eluviisi juurutavaid tekste. Eelduseks oli, et valitud tekstid pakuksid representatiivset läbilõiget materjalist. Valimis on esindatud olulisemad autorid ja mõjukad tekstid, mis võisid kujundada omaaegset keelekasutust üldisemalt. ${ }^{3}$

3 Vaimuliku kirjanduse tekste esindavad valimis Georg Mülleri jutlused (1600-1606); Heinrich Stahli „Hand- vnd Haußbuchi““ I osa (katekismus) (1632); Christoph Blume 
XX-XXI sajandi trükitekstide keelest võtsime uurimiseks Tartu Ülikooli eesti keele koondkorpuse 1990.-2000. aastate ilukirjanduse ja ajakirjanduse materjali. Mõlemad tekstikogumid on valitud omas žanris suhteliselt ühtlasest materjalist. Ilukirjandustekstide materjal pärineb allkorpuse „Eesti ilukirjandus 1990“4 realistliku proosa tekstidest. Ajakirjandustekstide materjal pärineb ühiskondlik-poliitilise ajakirja Luup tekstidest, mis esindavad ilukirjanduse materjaliga sama aega. ${ }^{5}$

Netikeelest valisime analüüsimiseks 2000.-2010. aastate netidialoogid ja -kommentaarid. Dialoogid pärinevad Tartu Ülikooli koondkorpuse netidialoogide allkorpusest ning kommentaarid Delfi ja Postimehe netiportaalide kommentaariumidest. Dialoogid on argivestlused tuttavate ja sõprade vahel. Need on sisult suhteliselt sarnased, sisaldades nii infovahetust kui ka sotsiaalsele suhtlusele orienteeritud dialoogi (ingl small talk). Tekstid valisime selliselt, et sama isik ei oleks esindatud kaks korda. Kommentaariumitekstid on anonüümsed kommentaarid mõne portaalis avaldatud lähteteksti kohta. Valimisse on võetud eriteemalised kommentaarid, et vältida konkreetse teema ja sellega seostuvate küsimuste üleesindatust. ${ }^{6}$

Igast tekstiliigist võtsime analüüsimiseks 100 juhuslikku korpustest küsimärgi alusel otsitud üldküsilauset, kokku 600 näidet.

Analüüsitud tekstid erinevad omavahel kuue parameetri poolest.

Esimeseks eristajaks on tekstide vanus. Vana kirjakeele tekstid pärinevad XVII ja XVIII sajandist, ülejäänud tekstid on tänapäevased. Valitud netitekstid on sealjuures uusimad tekstiliigid, mida varasemas keelekasutuses ei esinenud.

teosed „Geistliche Wochen-Arbeit“ (1666), „Geistliche Seelen-Ergötzung“ (1667) ja „Geistliche Hohe Fäst-Tahgs Freude“ (1667); 1715. a uus testament (Pauluse kiri roomlastele); 1739. a piibel (Saalomoni õpetussõnad). Õpetliku jutukirjanduse tekstigruppi kuulusid Anton Thor Helle 10 dialoogi (1732); pietistlik jutukogu ,Wiis head jutto“ (1740); August Wilhelm Hupeli „Lühhike öppetus ...“ (1766-67) ja „Arsti ramat“ (1771), Friedrich W. Willmanni „Juttud ja teggud“ (1782); Friedrich Gustav Arweliuse „Üks kaunis Jutto ja Öppetusse-Ramat“ (1782).

4 http://www.cl.ut.ee/korpused/segakorpus/eesti_ilukirjandus_1990/(autorid nt Ene Mihkelson, Olev Remsu, Aarne Ruben, Veiko Belials, Arno Kasemaa, Rein Põder, Lehte Hainsalu, Piret Bristol, Leo Kunnas, Aarne Biin, Reet Kudu).

5 http://www.cl.ut.ee/korpused/segakorpus/luup/.

6 Kommentaariteemade seas on poliitika, olümpiakomitee esimehe valimine, juuste pikkus, laste ohtlik mäng raudteel jm. 
Teiseks erinevad tekstid omavahel küsimuste suhetelt tegelikkusega. Netitekstides peavad osalejad tegelikku reaalajas dialoogi, trükitekstides tegelik dialoog kirjutaja ja lugeja vahel puudub.

Kolmandaks, suhtluse iseloom on netitekstide kahes alaliigis erinev. Netidialoogis kehtib suulisele dialoogile omane naabruspaari põhimõte (vt selle kohta Schegloff 2007: 13-21). Küsimus ja vastus moodustavad naabruspaari, milles küsimus kui paari esiliige tekitab vastuse ehk järelliikme ootuse. Kommentaariumis võib toimuda samuti suhtlus kommenteerijate vahel, kuid tavalisem on olukord, milles inimene esitab kommentaari (sh küsimuse kujul) ning seejärel rohkem sõna ei võta. Küsimused võivad seal olla suunatud ka teisele kommenteerijale, kuid kommentaariumisuhtluses puudub vastuse ootuse norm.

Neljandaks, trükitekstides esineb kahesugust dialoogi. Üks dialoog on tekstimaailmas osalevate inimeste vahel (ilukirjanduse ja õpetlike lugude tegelased, olemuslugude ja intervjuude suhtlejad). Siin erinevad omavahel ajakirjandus ja fiktsionaalsed tekstid, milles suhtlevad väljamõeldud tegelased. Teine dialoog on teksti autori ja potentsiaalse lugeja vahel, milles autor saab esitada lugejale suunatud küsimusi ja lugeja võib nendele omaette vastuseid otsida.

Viiendaks, valitud tekstiliigid erinevad suhete poolest kirjakeele normingutega. Netikeele tekstides puudub kirjakeele normingute järgimise surve. Sealne tegelik keelekasutus on kõikuv. Osa kirjutajaid järgib norminguid, osa kaldub neist kõrvale. Tänapäevased trükitekstid järgivad üldiselt kirjakeele norminguid ning normingupärasuse eest kannavad hoolt keeletoimetajad ja korrektorid. Sealjuures on ilukirjandus vähem norminguline, eriti dialoogis on lubatud kõrvalekalded (licentia poetica) ning autor võib seal imiteerida näiteks suulist argikeelt. Vana kirjakeele tekstides kehtivad oma aja tõlkelise (vaimuliku) kirjakeele tavad.

Kuuendaks, eri tekstiliigid on seotavad erinevate kontaktkeeltega. Vana kirjakeele tekstid on saksa keele mõjuväljas. Netisuhtluse keeles on märgitud tuntavat inglise keele mõju, kuigi otseseid võrdlevaid uuringuid pole tehtud. Praegusaja trükitekstid on eeldatavasti suhteliselt mõjuvabad, keeletoimetamine on pidanud oma rolliks võõrmõjude vähendamist.

Analüüsi käigus jagasime leitud küsilaused esmalt töörühma tüpoloogia alusel vormitüüpidesse (aluseks küsimarkerid, sõnajärg, sekundaarsed vormivahendid, küsimärk) ning seejärel analüüsisime iga küsimust eraldi 
ja määrasime tema funktsiooni. Kvalitatiivsele analüüsile järgnes materjali kvantitatiivne analüüs.

Meie uurimisküsimused koonduvad nelja rühma.

Esiteks, milliseid vormivahendeid vaadeldavates tekstiliikides üldküsimuse vormistamiseks kasutatakse?

Teiseks, erinevad tekstiliigid vajavad ja kasutavad eri funktsioonidega küsimusi. Milliste funktsioonidega küsimused on eri tekstides esindatud?

Kolmandaks, kuidas seostuvad küsimuste funktsioonid ja vormivahendid?

Neljandaks, valitud tekstid esindavad eri ajajärke, erinevat suhet tegeliku dialoogiga, kirjakeele normingute ja kontaktkeeltega. Kas need tegurid mõjutavad keelevahendite kasutust ning kui mõjutavad, siis kuidas?

\section{4. Üldküsimuse vormivahendid ja nende kasutus eri tekstiliikides}

Selles osas vaatame üldküsimuse vormivahendeid ja nende kasutust eri tekstiliikides. Eesti kirjaliku keele üldküsimuse vormivahendid on mitmekesised (vt tabel 3 lisas).

Esimese suure küsimarkerite rühma moodustavad lausealgulised küsipartiklid (164 kasutust kõigist vormivahenditest ehk 27\%). Sealjuures erinevad partiklite nomenklatuuri poolest vana kirjakeel ja tänapäeva keel.

Vanades vaimulikes tekstides on põhilised alguspartiklid kas ja eks 'kas ei', mille esinemiskordade hulk valimis on sarnane (kas esineb 22 ja eks 17 korda). XVII sajandi algusest pärinevates Georg Mülleri jutlustes leidub ka omapäraselt vormistatud sage küsilause tüüp, mida alustab kahesõnaline partikkel eb siis, nt $\boldsymbol{E} \boldsymbol{b}$ s̈̈ß se|sinane Lapsukene se|sama Ißandt olle, ka nente Pilwede sees murriseb? (Müller 1601). See võib olla eelastmeks XVII sajandi keskel põhjaeestilistes kiriklikes tekstides kasutatud eitavale küsipartiklile eps, nt eps hohlet Sa teps miño Waiwa perra? (Blume 1666). Omapärastest vormivahenditest võiks nimetada ka Anton Thor Helle dialoogides esinevat rahvapärast küsipartiklit jooks 'kas juba', nt P. Jooks loewad kokko? Lesen sie schon zusammen? (Thor Helle 1732). Alguspartiklite alla oleme liigitanud ka XVII sajandi vaimulikes tekstides kasutatud arhailise lausealgulise küsisõna onks. XVIII sajandi tekstides lüheneb see kujule ons, vrd Onks sesinnane Peh-Tük wanna Testamenti seês allustut? (Blume 1667); Ons nü̈̈d se / mis hä on / mulle surmaks sanud? Ei mitte. (UT 1715). 
XVIII sajandi jutukirjanduses on ülekaalukalt sagedasimad alguspartiklid eks ja kas, partiklid jooks ja ons esinevad seal harva. Tänapäevane partikkel ega ei esinenud kummaski vana kirjakeele valimis ühtki korda.

Tänapäeva tekstides valitseb alguspartiklite hulgas kas, harva leidub ka partiklit ega, nt Kuule, Sergei, ega see ometi mõni salakaup ole? (ILU). Kokkuvõttes näeme, et alguspartiklite mitmekesisus on tänapäeva keeles radikaalselt vähenenud.

Analüüsitud tekstid jagunevad lausealguliste küsipartiklite kasutussageduse alusel kaheks (vt joonis 1). Ühele poole jäävad vana kirjakeel ja tänapäeva ajakirjandus ning teisele poole ilukirjandus ja netikeel. Esimeses rühmas leidus alguspartiklitega küsimusi $35-48 \%$, teises rühmas $14-16 \%$ kõikidest küsimustest.

Teise suure rühma moodustavad küsimused, mis on vormilt väitlaused (97 kasutust 600-st ehk 16\%) või markeeritud ainult sekundaarse vormivahendiga (67 kasutust, koos väitlausetega 164 kasutust ehk 27\%). Siin näeme vahet vana ja tänapäevase kasutuse vahel (vt joonis 1). Vanas kirjakeeles on väitlauseline vormistus väga harv (14 kasutust ehk 7\%, koos sekundaarsete vormivahenditega 24 ehk 12\%). XVIII sajandil episteemilised üldlaiendid ning sidesõnalised vahendid alles hakkavad kujunema üldküsilause vormivahenditeks. ${ }^{7}$ Uue aja tekstides on see rühm oluliselt suurem (82 väitlauselist küsimust ehk $20 \%$, koos sekundaarsete vahenditega 140 kasutust ehk 35\%).

Lõpupartikkel või (eri variantidena) ja küsijätkud esinevad üksnes tänapäeva keeles, kokku 25 korda (6\%). Nende kasutusel erineb teistest netidialoogide keel, milles või on ainsana sage vormivahend (14\% valimist, nt sa loengus $\boldsymbol{v}$ (DIA)). Küsijätkud esinevad kõigis valimites väga harva (kokku 8 näidet), kusjuures 6 neist on netikeeles (aga sul ikka need kursused käivad selle sõiduteemalised eks? (DIA)). Algus- ja lõpumarkerite (kas $+v \tilde{v} i)$ kombinatsioon on samuti sagedasem netikeeles, eriti netidialoogides, mis on kooskõlas lõpupartikli või suure sagedusega selles

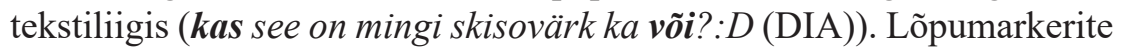
suure hulga tõttu erinevad netidialoogid teistest tekstiliikidest ka lõpu- ja algusmarkerite suhtelt: seal on alguspartikleid (14\%) ainsana kokkuvõttes vähem kui lõpumarkereid (18\%).

${ }^{7}$ Helle Metslang, Karl Pajusalu, Külli Habicht, Emergence of polar questions in discourse: from epistemic modality to interrogativity. Ettekanne Societas Linguistica Europaea 46. aastakonverentsil 19.09.2013 Splitis. 


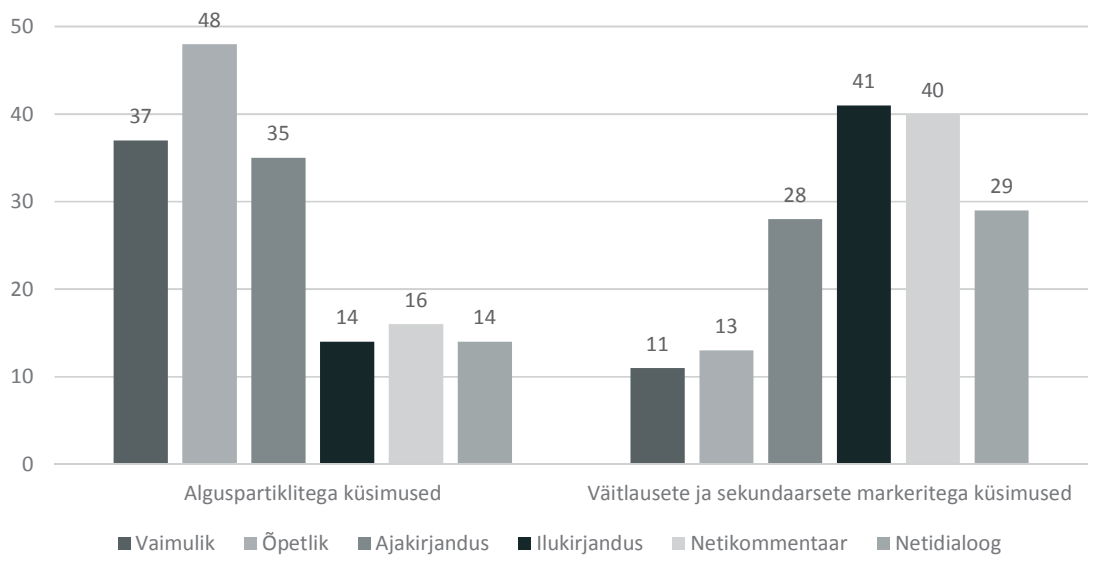

Joonis 1. Kesksete vormivahenditega üldküsimuste jaotumine tekstiliigiti $\%^{8}$

Sõnajärge on üldküsimuse vormistajana kasutatud 58 korda (14\%). Silma torkab see, et saksa keele eeskujuline inversioon on ainsana sage vaimulikus kirjanduses (24 kasutust kogu materjali 34 inversioonijuhust), nt Tahat siña Ristitut sada? Wilt du Getauffet sein? (Stahl 1632). Inversiooni kasutus väheneb juba õpetliku jutukirjanduse tekstides ning esineb edaspidi vaid marginaalselt (vt lisast tabel 3). Lausealguliste partiklite ja inversiooni suhtelt erinebki teistest vaimulik kirjandus, kus leidub 37 partikliga vormistatud küsimust ja selle kõrval koguni 24 inversioonijuhtu.

Üldistavalt võib öelda, et küsimuse vormivahendite kasutuse poolest erinevad selgelt vana ja tänapäeva keel. Vanas keeles valitsevad lausealgulised partiklid ja puuduvad lauselõpulised markerid. Ühtlasi näeme, et alguspartiklite nomenklatuur on vanas keeles mitmekesine ja tänapäeva keeles kitsas. Lauselõpuliste markerite nomenklatuuriga on vastupidi: need puuduvad vanas kirjakeeles ja neid on tänapäeva keeles üsna mitmesuguseid (või,jah, eks, onju, eksole). Sealjuures on näha, kuidas uusimas keelevariandis ehk netikeeles on lauselõpuliste markerivariantide hulk suurenenud, nt $v \tilde{o} i$ ja $v \ddot{a}$ kõrvale on tulnud kujud ve, $v, w$, kusjuures lühivariandid $v$ ja $w$ on eriti tavalised netidialoogide keeles.

8 Kõiki vormivahendeid vt tabel 3 (lisas). 
Väitlausena ja sekundaarsete vahenditega vormistatud üldküsimus on väga sage tänapäeva keeles ning harv vanas keeles.

Kesksete vormivahendite esindatust tekstiliikide kaupa näitab joonis 2 .

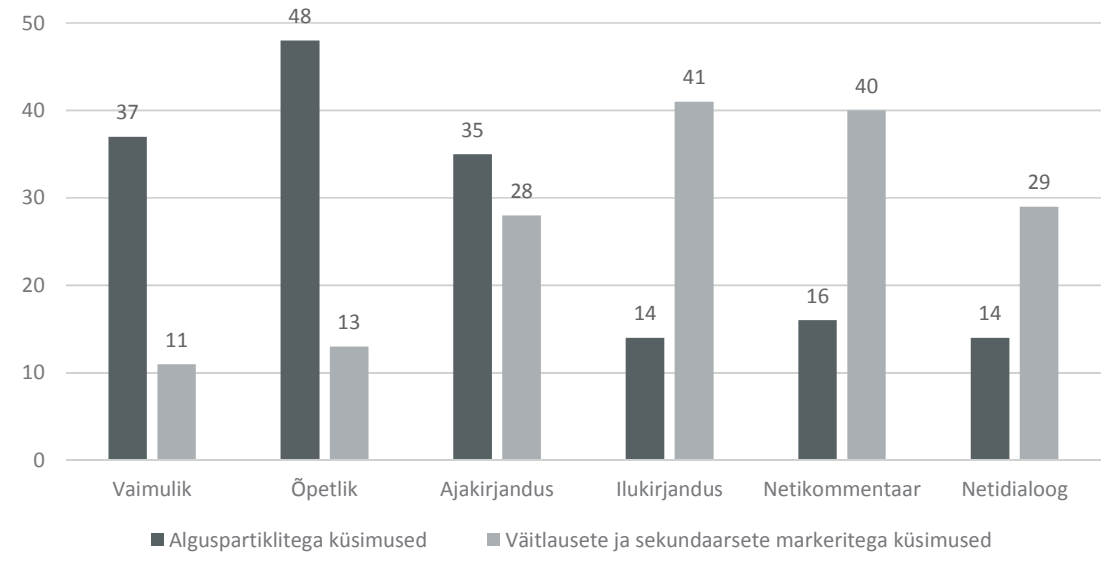

Joonis 2. Kesksete vormivahenditega üldküsimuste esinemine tekstiliigiti \%

Samas ei erine üksnes vana ja tänapäeva keel. N-ö keeleõpikulik üldküsimuse märgistus (alguspartikkel või inversioon) on valitsev ainult 300-400 aasta tagustes tekstides (111 kasutust 200-st). Uuemal ajal leidub seda teistest rohkem ajakirjanduses (38\%), muudes tekstiliikides jääb nende vahendite kasutus $16-20 \%$ vahemikku.

\section{5. Üldküsimuse funktsioonid ja nende seosed tekstiliikidega}

Selles osas kirjeldame erineva funktsiooniga üldküsimuste kasutust eri tekstiliikides (vt ka tabel 4 lisas). Analüüs näitab, et üldküsimuse põhiline funktsioon kõigis tekstiliikides peale vanade vaimulike tekstide on kinnituse soov (oletus- ja kahtlusküsimused), mis moodustab 56-75\% kõigist küsimustest (vt joonis 3). 


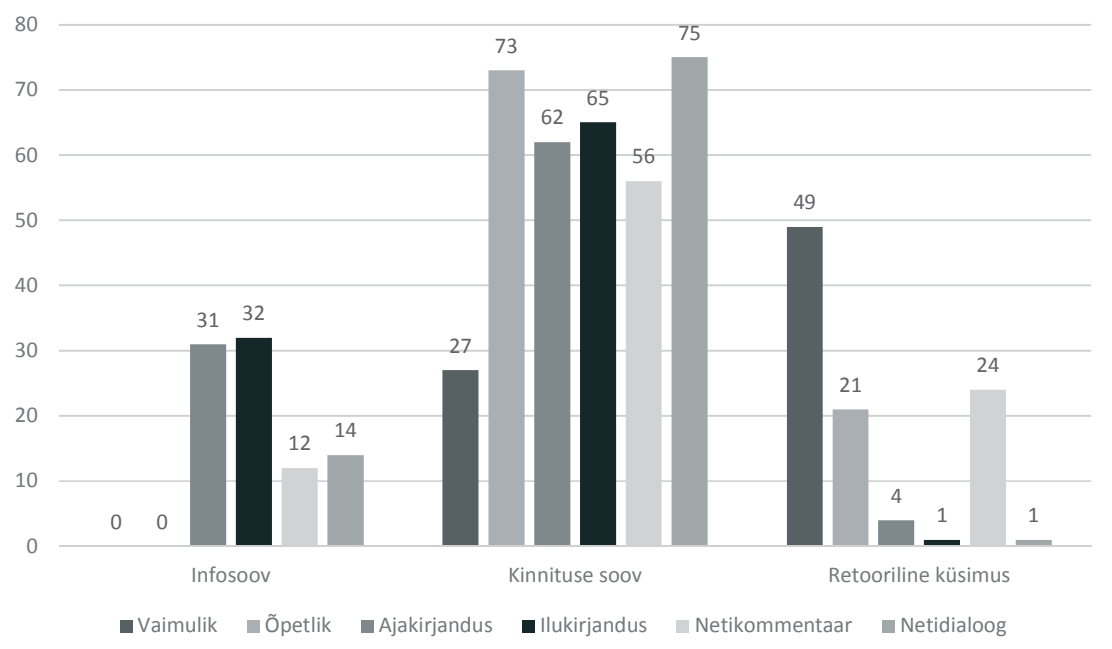

Joonis 3. Kesksete funktsioonidega üldküsimuste jaotumine tekstiliigiti \%

Kui üldiselt on suurem oletusküsimuste osakaal, siis vana kirjakeele vaimulikes ja õpetlikes tekstides on ülekaalus kahtlusküsimused, nt Eks need keik polle jo ramato mehhed? Können diese alle nicht schon lesen? (Thor Helle 1732). Põhjus võib olla selles, et kahtlusküsimus on olemuselt lähedasem vanades tekstides olulisele retoorilisele küsimusele. Mõlema puhul eeldatakse küsimuse vormile eituse-jaatuse (polaarsuse) skaalal vastandlikku vastust või tõlgendust.

Oletusküsimusi vaimulikes tekstides ei leidu, need lisanduvad alles XVIII sajandi õpetlikus jutukirjanduses. Samas suureneb õpetliku jutukirjanduse tekstides ka kahtlusküsimuste osakaal (27\%-lt 53\%-le) ning väheneb retoorilise küsimuste oma (49\%-lt 21\%-le).

Tänapäeva tekstides on oletusküsimus peamine üldküsimuse funktsioon olenemata tekstiliigist, nt ,Ehk on asi vaid selles, et su eesti helilooja oli nõukogude ajal elav klassik, aga nüüd peaaegu põlualune?" (ILU), „Puškin, eks? “(ILU), nüüd jääd kauemaks Tartu jah? (DIA). Selle kõrval leidub ka kahtlusküsimusi, nt Kas Eesti riigi püha kohus ei ole aidata kaasa soolise diskrimineerimise vähendamisele tööturul? (AJA). Netisuhtluses erinevad omavahel dialoogid ja kommentaarid. Kommentaarides on oletusküsimusi oluliselt vähem kui dialoogides (vastavalt 38\% ja 61\%). Samas on seal küsimusi, mis jäävad retooriliste küsimuste ja kahtlusküsimuste 
piirile ning väljendavad tihti kirjutaja iroonilist või mõnitavat suhtumist, nt küsimus Kas keegi käib veel valimas? (KOMM).

Infosoovide osakaal jääb kõigis tekstiliikides alla 32\%. Sealjuures on neid rohkem ilu- ja ajakirjanduses (31-32\%), teistes liikides jääb nende kasutus $0-14 \%$ vahele (joonis 3 ). Infosoovide puudumine vana kirjakeele tekstivalimis võib tuleneda usulise ja õpetlik-moraliseeriva tekstiliigi retoorilis-pragmaatilisest eripärast. Sellistes tekstides vahendatakse pigem hoiakuid või soovitakse vastajalt kinnitust ja neis ei esine päris infodialoogi. Infoküsimusi väljendavad nendes tekstides eriküsilaused.

Ajakirjandustekstide peamine funktsioon ongi info vahendamine, $\mathrm{nt}$ Kas ühiskonnas võib täheldada usulise tervenemise märke? (AJA). Ilukirjandusdialoogide infosoovide sagedasemaid ülesandeid on juhatada sisse uusi allteemasid, nt „, Kas siin „Družba “ ketid ja noad ka käiku lähevad? “ jõudsin küsida, enne kui taipasin, et küsin vale inimese käest. (ILU).

Nn kooliküsimused (katekismuseküsimused) esinevad ainult vaimulikes tekstides. Need ei moodusta päris puhtaid tüüpe, kuid ka neist viitab veidi suurem osa (15\%) oletusküsimustele ja väiksem hulk (9\%) kaldub infosoovide poole, nt Ons nü̈̈d se / mis hä on / mulle surmaks sanud? Ei mitte. (UT 1715).

Küsimuste vormis direktiive kasutatakse tänapäeval rohkem netisuhtluses (kommentaarides $8 \%$ ja dialoogides 11\%). Netidialoogides on valdavad konkreetsed ettepanekud või pakkumised, millele oodatakse kinnitust, nt kas lepime kohe mingi aja kokku? (DIA), Aga täna õhtul lähme välja ka eksju (DIA). Kommentaarides on samuti valdavad ettepanekud ja pakkumised, nt saad 60 EUR-i kuus. Teeme ära? (KOMM), Järsku võtaks ikka aluseks ka rongi kiiruse ja mõned ilmaolud ka (KOMM). Need erinevad siiski dialoogide direktiividest. Esiteks on osa neist suunatud kogu kommenteerivale seltskonnale või abstraktsele adressaadile. Teiseks sisaldavad viis neist ka etteheidet, nt Äkki lähed magad kaineks ennast? (KOMM). Samasugused direktiivsed etteheidet sisaldavad küsimused esinevad ka õpetlikus jutukirjanduses, nt Eks sa woiks mitte ärrajoosta, kus so jallad ollid? 'Kas sa ei oleks võinud ära joosta ..' (Willmann 1782).

Vana kirjakeele mõlemale tekstiliigile on omane retooriliste küsimuste suur osakaal (vt joonis 4), nt Kas siis nende uskmatta Meel Jummala Usko peaks tühjaks teggema? (UT 1715). Õpetlikus jutukirjanduses võib võrreldes vaimulike tekstidega näha retooriliste küsimuste osakaalu vähenemist, mis osutab vaimuliku tekstiliigi eeskuju nõrgenemisele kirjakeeles ja näitab 
dialoogide ilmselt teadlikku lähendamist reaalsetele suhtlusolukordadele. Palju retoorilisi küsimusi leidub ka netikommentaarides, kuid netidialoogides need peaaegu puuduvad.

Retoorilised küsimused esitavad küsimuse vormis seisukohti, arvamusi, hinnanguid. Tüüpiliselt on need pööratud polaarsusega küsimused, milles seisukoht ja seda väljendav vorm on grammatiliselt vastupidised (vt Laanesoo 2012). Jaatavas vormis lause Pärast poos bursuid üles ja kas proletariaat sai õnnelikuks või? (KOMM) esitab arusaama, et proletariaat ei saanud õnnelikuks. Kommentaariumides esitatakse ennekõike oma arvamusi, selle tõttu on seal rohkesti ka retoorilisi küsimusi.

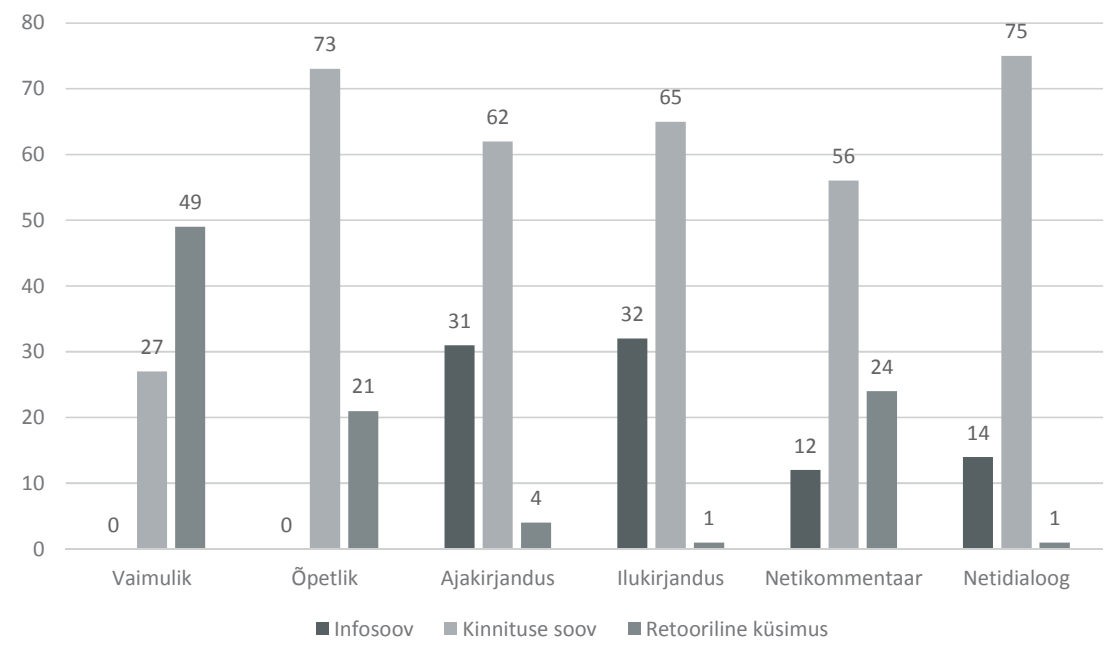

Joonis 4. Kesksete funktsioonidega üldküsimuste esinemine tekstiliigiti \%

Niisiis valitseb kinnituse soov kõigis tekstiliikides nii vanas kui ka tänapäevases keeles. Infosoov ehk küsimuse baasfunktsioon on üldküsimuse jaoks sekundaarne roll. Sealjuures on selle sagedus nt netikeele näidetes sama suurusjärku direktiivi vormistamise rolliga (infosoovi osakaal 12\% kommentaarides ja 14\% dialoogides, direktiivi osakaal vastavalt $8 \%$ ja $11 \%$ ) (vt joonis 4). 


\section{6. Üldküsimuse vormi ja funktsioonide seosed}

Selles osas toome välja küsimuse vormivahendite ja funktsioonide seosed tekstiliikide kaupa. Alguses vaatame seoseid funktsioonist ja seejärel vormivahenditest lähtudes.

Infosoovid esinevad ainult tänapäevastes tekstides. Ilukirjanduses ja ajakirjanduses on nende valitsev vormivahend lausealguline küsipartikkel (40 kasutusjuhtu 63 infosoovist), valdavalt kas, nt „,Kas sa minu šifreeritud sõnumid said kätte?" kõlas Luige esimene küsimus (ILU). Selle kõrval võib kas esineda koos muude primaarsete vahenditega, ennekõike sõnajärjega, nt Kas õnnestus Kalevil mõnele neist pärandada tema valdusest tasapisi ära nihkunud taevanaba? (AJA). Partikli kõrval viitavad infosoovile ka inversioon ja verb lause alguses (kokku 8 kasutust), nt ,Said sa aru? “ (ILU), ning alguspartikli ja verbi asukoha muutmise kombinatsioonid (12 kasutust), nt Kas võib see tähendada, et mingi osa Kalevipoja tembutustest hoopis vene muinaskangelase Dobrõnja Nikititshi arvele kanda võib? (AJA), Kas julgeoleku ohvitseri meenutamine temas ka enam kaitsetuse ja hirmu elamusi esile ei kutsu? (ILU).

Netitekstides on infosoovid väljendatud samuti enim lausealgulise küsipartikliga (13 kasutust 26-st, nt kas sul 2. küsimus on vastatud? (DIA)), mille kõrval on palju ja hajuvalt ka muid vahendeid.

Väitlaused, lauselõpulised küsimarkerid ja sekundaarsed vormivahendid esinevad selles rollis mõlemas tekstirühmas vaid harva ja hajali.

Kahtlusküsimused esinevad kõigis tekstiliikides. Vanades tekstides vormistatakse need valdavalt lausealgulise küsipartikliga (49 kasutust 80-st), nt Kas teie sedda woite pühhast kirjast töeks tehha? (Viis head juttu 1740). Kui lisada kasutusjuhud, milles on alguspartikkel koos mõne sekundaarse vahendiga, siis saame kokku 71 kasutust ehk 89\% kõikidest vanade tekstide kahtlusküsimustest.

Tänapäeva trükitekstides on kahtlusküsimused vormistatud samuti valdavalt alguspartikliga. Kahtlusele võib seejuures viidata leksikaalsete vahenditega, nagu hetkegi, midagi, ometi, üldse: ,, Kas sa ei kõhelnud hetkegi, kui ma sind tšaihanaasse saatsin? “(ILU), ,Ega ometi mulle?" üritas Elli nalja teha (ILU). ${ }^{9}$ Teiseks kahtlusküsimuse tüüpiliseks vormivahendiks

9 Siinsesse artiklisse ei mahu lausete struktuurijoonte, nagu eituse ning eitus- ja jaatuslembese leksika käsitlus. Üldiselt on täheldatud, et eitavavormilised küsimused kalduvad olema kinnitust küsivad. Uuritud tänapäevastes trükitekstides on eitavavormilised küsilaused valdavalt kahte tüüpi: alguspartikliga kahtlusküsimu- 
on küsipartikli ja sekundaarse vormivahendi kombinatsioon, nagu kas tõesti või kas aga: Kas tõesti on ajakirjandus järjekindlalt Mõisa mõtteid moonutanud? (AJA). Intervjuudes esitatava kahtlusküsimuse tüüpiliseks vormiks on lause, mis algab partikliga kas, aga lause lõpus toob kahtluse esile fokuseeritud eitav verbivorm: Kas teised majandussektorid väljaspool transiiti ei ahvatle? (AJA).

Netitekstides on kahtlusküsimused erinevalt trükitekstidest vormistatud paljude vahenditega, millest ükski statistiliselt esile ei tõuse.

Oletusküsimused esinevad vanades tekstides ainult õpetlikus jutukirjanduses, kus põhiliseks vormistajaks on samuti lausealguline küsipartikkel (16 kasutust 20 küsimusest), kuid erinevalt kahtlusküsimustest on siin suhteliselt rohkem sekundaarseid vormivahendeid (12 kasutusjuhtu), nt Kas teie siis ramatust moistate luggeda ja laulda? Versteht ihr dann auch ausm Buche zu singen und zu beten? (Thor Helle 1732).

Tänapäeva trükitekstides on oletusküsimuste vormistamiseks mitu sagedast viisi. Põhiline vormivahend on väitlause (34 kasutust 83-st). Ilukirjanduses on selleks tüüpiliselt eelnevat eriküsimust täpsustav sõna või fraas, nt [Kes sellest rääkis?] Tuhkna? (ILU). ${ }^{10}$ Ajakirjandustekstides on sellised küsimused enamasti täislaused, nt Noortevanglast tulevad n- $\ddot{o}$ suuremad kiskjad? (AJA). Teise suurema rühmana tulevad esile sekundaarsed vahendid (22 kasutust). Sealjuures võib selline marker paikneda nii lause alguses, nt $\ddot{A} \boldsymbol{k k i}$ lihtsalt ei näidata kasumit? (AJA), kui ka lause sees, nt Neid, kellel ,, sellist masinat" laua peal pole, on ju enamus? (AJA). Esimesel juhul on küsilause vormistus lähedane küsipartikliga markeerimisele, teisel juhul sarnaneb lause pigem puhta väitlausega. Kolmas tavalisem vormivariant on sõnajärje muutmine koos sekundaarse vahendi kasutusega, nt Enam kui kord oli mõnigi poistest ligi astunud, tasakesi pärides: ,, Vahest on sul mõni tukk veel alles? “ (ILU) (vt joonis 5).

sed, nt Kas Eesti riigi püha kohus ei ole aidata kaasa soolise diskrimineerimise vähendamisele tööturul? (AJA), ja sekundaarse vahendiga või väitlausekujulised oletusküsimused, nt Aga niisugust riiki enam justkui ei eksisteeri? (ILU). Eelistust aitavad väljendada eitus- või jaatuslembesed sõnad, intensiivistavad ja episteemilised üldlaiendid, hinnanguline leksika, eitava verbivormi fokuseerimine lause lõpus, nt Kas härral tõesti südant sees ei ole? (ILU), ,, Kuule, Sergei, ega see ometi mõni salakaup ole?" (ILU). (Vt Metslang 1981: 35-42.)

${ }^{10} \mathrm{Vt}$ selliste eriküsimuse ja üldküsimuse paaride kohta suulises suhtluses Rumm 2015: 57-70. 
Netitekstides on oletusküsimused vormistatud samuti paljude vahenditega. Nende seas tõusevad esile väitlaused (23 kasutust, nt sa tuled ka homme? (DIA)), sekundaarsed vahendid (14 kasutust, nt ise lähed suusatama ju? (DIA)) ning lauselõpulised küsipartiklid ja küsijätkud (16 kasutust: aga sul ikka need kursused käivad selle sõiduteemalised eks? (DIA)). Kokku annavad need 53 kasutust 99-st (vt joonis 6).

Kokkuvõttes näeme, et oletusküsimused on tänapäeva tekstides vormistatud ennekõike väitlausetena ja sekundaarsete vahenditega. Netidialoogides tõusevad uue sagedase vahendina esile lauselõpulised küsipartiklid (16 kasutust, vrd trükitekstide 3 kasutust) (vt joonised 5 ja 6).

Retoorilised küsimused on vanades tekstides moodustatud mitmete vahenditega. Kasutusel on inversioon üksi ning koos sekundaarsete vahenditega (26 kasutust), küsipartikkel üksi ning koos sekundaarsete vahenditega (22 kasutust), harvemini ka väitlause (10). Sealjuures erinevad vaimulikud ja õpetlikud tekstid retooriliste küsimuste vormistamisel. Varases vaimulikus kirjanduses on retooriline küsimus kõige sagedamini vormistatud inversiooniga (17 küsimust 24-st, nt Peax Iumal mittekit toiwutama, ninck eb mittekit tegkema? 'Kas Jumal ei peaks midagi tõotama ega midagi tegema?' (Müller 1605)), samal ajal kui õpetlikus jutukirjanduses on inversioon taandunud teisejärgulisse rolli ja keskseks on tõusnud lausealguline küsipartikkel (12 juhtu 21-st, nt Kas see kange kibbe wiin ning selle kurri hais sulle ni wägga maggus on? (Hupel 1766)). Tänapäevastes tekstides on retoorilisi küsimusi väga vähe ning nende vormistus on ebaühtlane.

Direktiive leidub vanades õpetlikes tekstides (6 kasutust), kus neid vormistab lausealguline küsipartikkel, nt [Oh sinna sallalik!] eks sa nenda pead walletama? (Willmann 1782). Ilukirjanduses ja ajakirjanduses esinevad vaid üksikud üldküsimuse vormis direktiivid. Netitekstides esineb direktiive rohkem (kokku 19 kasutust). Üheksal juhul on direktiiv seal vormistatud üksnes sekundaarse vahendiga (mõtlesin, et võiks kinno minna $\ddot{a} \boldsymbol{k} k \boldsymbol{i}$ ? (DIA)) ning viiel juhul primaarse ja sekundaarse vahendiga. Seega võib öelda, et direktiivide vormistust netitekstides iseloomustab suur sekundaarsete vahendite hulk.

Kooliküsimused esinevad vaid vaimulikus kirjanduses (24 kasutust), kus need on samuti enamasti vormistatud lausealgulise küsipartikliga (10) või küsipartikli ja sekundaarse vahendiga (5), muudest vahenditest on sagedasem inversioon (6 korda). Olgu näiteks alguspartikliga kas ja 


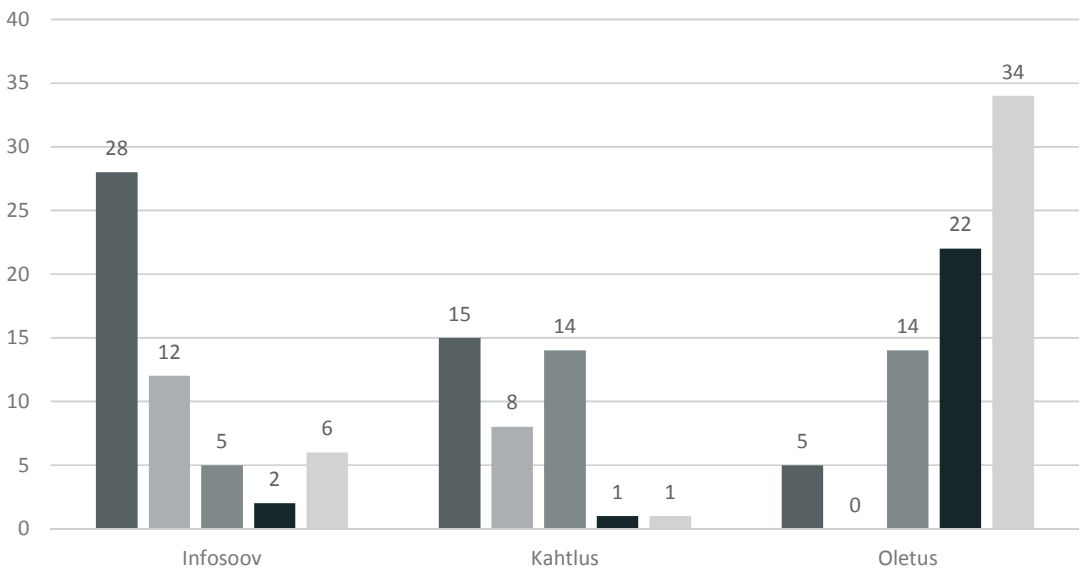

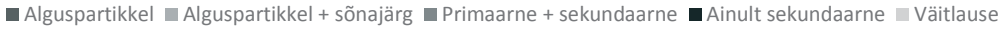

Joonis 5. Üldküsimuse kesksed funktsioonid ja vahendid aja- ja ilukirjandustekstides $\%$

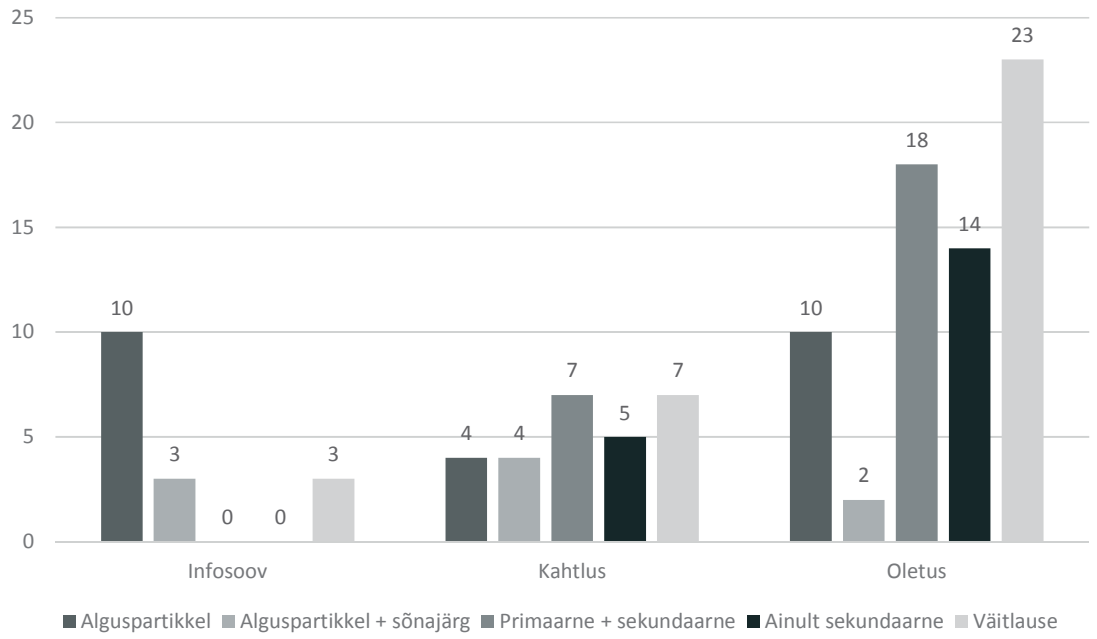

Joonis 6. Üldküsimuse kesksed funktsioonid ja vahendid netitekstides \% 
sekundaarse vahendiga siis vormistatud kooliküsimus, millele on lisatud ka oodatav vastus: Kas siis meie Käsko tühjaks teme Ussu läbbi? Ei mitte / waid meie kinnitame Käsko. (UT 1715).

Vormivahendite poolelt vaadates saame öelda, et vanades tekstides on küsipartikkel analüüsitud materjalis ennekõike kahtlusküsimuse vormistamise vahend (49 kasutust 85-st), kuigi see on piisavalt sagedane ka mujal. Infosoove ei leidu vana kirjakeele materjalis ilmselt nende tekstide retoorilise eripära tõttu. Inversioon on valdavalt retooriliste küsimuste vahend (17 kasutust 24-st), samuti väitlause.

Tänapäeva trükitekstides täidab lausealguline küsipartikkel primaarselt infosoovi vormistaja rolli, lauselõpulised markerid, sekundaarsed vahendid ning primaarse ja sekundaarse vahendi kombinatsioonid on valdavalt kinnituse soovi vormistajad.

Netitekstides on lausealgulise küsipartikli kasutus osalt erinev, täites seal nii info- kui ka kinnituse soovi vormistaja funktsiooni. Samas väitlaused, sekundaarsed vahendid ning lauselõpulised küsimarkerid vormistavad valdavalt kinnituse soovi.

Mõlemas tänapäevases tekstirühmas paistab silma see, et sekundaarsed vahendid seostuvad ennekõike oletusküsimustega (vähem ka kahtlusküsimustega) ja peaaegu üldse mitte infosoovidega. See võimaldab ettevaatlikult järeldada, et sekundaarsed vahendid, eriti episteemilised üldlaiendid, annavad kinnitust ootava varjundi ka küsimusele, mis on vormistatud lausealgulise küsipartikli kui prototüüpse infosoovi vahendiga.

\section{Kokkuvõttev arutlus}

Analüüs näitab, et üldküsimuse vormivahendite kasutuse ja nomenklatuuri poolest erinevad selgelt vana ja tänapäevase kirjaliku keele tekstid. Vanas keeles esinevad üksnes lausealgulised küsipartiklid, mille nomenklatuur on mitmekesine (kas, eks, eb siis, eps, jooks, onks, ons). Tänapäeval on alguspartiklite nomenklatuur väike (kas, ega). Lauselõpuliste küsimarkerite nomenklatuur on käitunud aga vastupidi: need puuduvad vanas keeles, samal ajal kui tänapäeval leidub väga erinevaid lõpumarkereid (või/vä/ve/v/w, jah, eks, onju). Lisaks on väitlauselise ja sekundaarsete vahenditega üldküsimuse vormistus vanas keeles väga harv ja tänapäeva keelekasutuses väga sage. Kokkuvõttes paistab üldküsilause vormistuses välja kaks suundumust. Esiteks on näha markerite liikumist lause algusest 
lause lõppu. Teiseks kujunevad ja lisanduvad kasutusse sekundaarsed vahendid (Metslang jt 2015). ${ }^{11}$

Analüüsitud tänapäevased tekstiliigid erinevad oma suhetelt kirjakeele normingutega. Küsimuse vormivahendite kohta leidub õigekeelsusallikates või õpikutes vaid üksikuid otseseid soovitusi (nt Erelt 2006: 69). Siiski on keelehooldepraktikute kirjutamata reegliks olnud arusaam, et üldküsimuse põhiline või alati sobiv vormivahend on kas-küsimus. See on näiteks ainuvaldav norminguid järgivates õigustekstides ja riigikogu stenogrammides (Metslang 2010). Otseselt suulise argikeelega on keeledebattides seostatud lõpupartiklit või/vä, mis on ilukirjanduses kasutusel vähemalt XIX sajandi lõpust alates. ${ }^{12}$ Nii väidab Henn Saari, et kas sobib kõigisse üldküsimustesse ja või-küsimus on lõdvema ja lohakama tavakeele vahend (Saari 1976: 3-5). Talle vaidleb vastu tõlkija Henrik Sepamaa, kes toob näiteid kirjandusklassikute A. H. Tammsaare, August Kitzbergi ja Eduard Vilde ilma kas-sõnata vormistatud küsimuste kohta (Sepamaa 1978).

Analüüsitud materjal kinnitab toodud seoseid. Kas esineb oluliselt sagedamini kõige rangemalt kirjakeele reegleid järgivates ajakirjandustekstides (35\%), samas kui ilukirjanduses ja netikeeles on selle sagedus 14-16\%. Võ i sagedus oli ainsana suur argises netidialoogis, mujal esines see vaid marginaalselt. Samas ei saa või kasutust siduda ainult argikeelega. Kuna seda tarvitatakse laialt ka institutsionaalses suulises suhtluses, siis võib selle kasutust siduda pigem suulise keelega üldiselt (vt Hennoste jt 2013: 14).

Verbiga algavat, kuid ilma inverteeruva elemendita küsimuse vormi on võinud soodustada peale eesti keelele omase pronoomeni väljajätu (nn pro-drop) ning ökonoomiatendentsi ka võitlus inversiooniga kaasneva „memetamise-tetetamise“ vastu (nt Saari 1976: 5), nt Olete rahul? (AJA), selmet küsida Olete te rahul?. Verbiga algavat küsimust leidub ennekõike ajakirjandustekstide ja netikommentaaride küsimustes, kus puuduvaks aluseks on sageli mitmuse teise isiku pronoomen.

${ }^{11}$ Vt ka Helle Metslang, Karl Pajusalu, Külli Habicht, Emergence of polar questions in discourse: from epistemic modality to interrogativity. Ettekanne Societas Linguistica Europaea 46. aastakonverentsil 19.09.2013 Splitis.

${ }^{12}$ Näiteks Oskar Lutsu „Kevade“ Tali ja Tõnissoni dialoog: ,,Jaa, aga kui ma võru ei too, siis ... siis hakkab tema ise Teelega plaani pidama. “.. Veidi aja pärast Tõnisson küsis: „Ah Toots või??“(Oskar Luts, Kevade. Tallinn: Eesti Raamat,1986, lk 20). 
Teiseks jälgisime eri funktsiooniga üldküsimuse kasutust erinevates tekstiliikides. Analüüs näitab, et kirjalike tekstide üldküsimuse valitsev funktsioon on kinnituse soov (oletus- ja kahtlusküsimused), mis moodustab 1/2-3/4 kõigist küsimustest. Grammatikates küsimuse keskse rollina nimetatud infosoovi sagedus jääb kõigis tekstiliikides alla 1/3. Sealjuures on rohkem infosoove ilu- ja ajakirjanduses (31-32\%), teistes liikides jääb nende osakaal $0-14 \%$ vahemikku.

Nõnda sarnaneb kirjaliku keele üldküsimus funktsioonidelt suulise keele üldküsimusega. Nt eesti suulises institutsionaalses suhtluses moodustavad kinnituse soovid 56\% üldküsimustest, samal ajal kui infosoovi on 15\% (Hennoste jt 2013: 14-15). ${ }^{13}$ Seda ei saa siiski pidada eesti keele erijooneks, sest sama kehtib näiteks indoeuroopa keelte argisuhtluses, mida on uuritud Max Plancki instituudi projektis. Inglise keeles moodustab kinnituse soov 70\% ning infosoov 27\% üldküsimustest (Stivers 2010: 2776).

Seega võime öelda, et kirjalik eesti keel järgib üldküsimuste funktsioonides tegelikku suulist dialoogi. Keskne funktsioon ei sõltu sealjuures tekstide loomise ajast, tekstiliikidest ega küsimuste seostest tegelikkusega. Eriti oluline on, et küsimuste keskset rolli ei muuda see, kas tegemist on tegeliku dialoogilise suhtlusega (nagu suulises suhtluses ja netidialoogis) või autori loodud tegelaste suhtlusega (nagu ilukirjanduses).

Erinevused kirjalike tekstiliikide vahel ilmnevad ennekõike üldküsimuse abil vormistatud retooriliste küsimuste ja direktiivide kasutuses. Retooriliste küsimuste osakaal on suur vana kirjakeele vaimulikus ja õpetlikus jutukirjanduses ning netikommentaarides. Direktiivide osakaal on suur õpetlikes tekstides, netikommentaarides ja netidialoogides. Kahte rolli koos vaadates on omavahel sarnased XVIII sajandi õpetlikud tekstid ja tänapäeva netikommentaarid. Mõlemas esitatakse palju direktiive ja seisukohti küsimuste abil. See teema vajab aga edasist täpsemat uurimist.

Kolmandaks uurisime korrelatsiooni üldküsimuste funktsioonide ja vormi vahel.

Siin võrdlesime infosoove ja kinnituse soovide kahte alaliiki, kuna muude funktsioonidega küsimusi on osas tekstiliikides väga vähe. Analüüs näitab, et tänapäeva eesti kirjalikus keeles valitseb üldküsimuse funktsioonide ja küsivahendite suhetes ühtsus.

${ }^{13}$ Hennoste jt 2013 kasutab siinsest erinevat terminoloogiat. „Kinnituse soov“ on selles „,vastust pakkuv küsimus“ ja ,infosoov“ on „,suletud kas-küsimus“. 
Infosoovi vormistajana eelistavad kõik neli tänapäevast tekstiliiki lausealgulist küsipartiklit ja inversiooni ning küsipartikli ja verbi ümberpaigutamise kombinatsiooni. Samal ajal kasutavad kõik tekstiliigid selles rollis vähe või väldivad lauselõpulisi küsimarkereid, ainult sekundaarseid vahendeid või väitlauseid.

Ka oletuse vormistamisel käituvad tekstiliigid ühtmoodi. Ennekõike on siin kasutatud vormivahendeid, mida infosoovide vormistamisel on välditud: väitlauseid, sekundaarseid vahendeid ning lauselõpulisi küsimarkereid. Sealjuures erineb teistest netidialoogide keelekasutus, kus ainsana on lauselõpuliste markerite kasutamine sage.

Kahtlusküsimuse väljendamiseks on trükitekstides ja netikommentaarides eelistatud infosooviga sarnaseid vahendeid. Netidialoogide kahtlusküsimustes on kasutatud hajali paljusid vormivahendeid.

Kokkuvõttes näeme, et üldküsimuste funktsioonide ja vormivahendite seos on olnud püsiv. Vahendite eelistust ei ole muutnud tekstide suhe normingutega, küsimuste tegelikkus või fiktsionaalsus, naabruspaari põhimõtte järgimine või mittejärgimine ega erinevad suhted kontaktkeeltega.

Eesti suulise keele analüüse ei saa üheselt siinsete tulemustega võrrelda, sest nendes ei ole eristatud oletus- ja kahtlusküsimusi ega eraldi välja toodud sekundaarseid vahendeid. Üldiselt aga kehtib eesti suulises institutsionaalses dialoogis sama funktsioonide ja vahendite seos. Seal on infosoovid vormistatud valdavalt partikli kas abil ning kinnituse soovid valdavalt väitlause, partiklite jah ja või abil (Hennoste jt 2013: 13, 16).

Analoogiline suhe kehtib ka inglise keeles, kus infosoove väljendab peaaegu üksnes inversioon ning kinnituse soove väitlause, harva ka küsijätk (Stivers 2010: 2776). Samas ei kehti see eristus kõigis keeltes, nt taani ja hollandi keeles eelistatakse küll infosoovi väljendamiseks inversiooni, kuid kinnituse soovide tarvis kasutatakse suure sagedusega mitmeid erinevaid vahendeid (vt Englert 2010; Heinemann 2010). Ka nendes analüüsides ei eristatud oletus- ja kahtlusküsimusi. Seega on võimalik, et vormilised erinevused peegeldavad siin tegelikult valimisse sattunud küsimuste funktsionaalseid erinevusi.

Vaadates vahendi ja funktsiooni suhteid vahendite poolelt, saame järgmise pildi. Lausealguline küsipartikkel täidab tänapäeva trükitekstides primaarselt infosoovi vormistaja rolli. Samas on lõpumarkerid, sekundaarsed vahendid ning primaarse ja sekundaarse vahendi kombinatsioonid valdavalt kinnituse soovi vormistamise rollis. 
Netitekstides vormistab lausealguline küsipartikkel nii info- kui ka kinnituse soovi. Võib oletada, et alguspartikli funktsioon infosoovi vormistajana on hakanud hajuma. Lauselõpulised küsipartiklid, sekundaarsed vahendid ning primaarse ja sekundaarse vahendi kombinatsioonid on seevastu peaaegu ainult või valdavalt kinnituse rollis.

Oluline erinevus tuleb esile ka sekundaarsete vahendite kasutuses kas üksi või koos primaarsete vahenditega. Mõlemas tänapäevases tekstirühmas paistab silma see, et sekundaarsed vahendid seostuvad ennekõike oletusküsimustega (vähem ka kahtlusküsimustega) ega seostu peaaegu üldse infosoovidega. See võimaldab arvata, et sekundaarsed vahendid, eriti episteemilised üldlaiendid, annavad kinnitust ootava varjundi küsimusele, mis on vormistatud lausealgulise küsipartikli kui prototüüpse infosoovi markeriga.

Vanades tekstides ei esine puhtaid infosoove ning puuduvad lauselõpulised küsimarkerid ja sekundaarsed vahendid. Seal täidavad lausealgulised küsipartiklid valdavalt kinnitust ootava küsimuse rolli. Inversioon on aga vaimulikes tekstides põhiliselt retooriliste küsimuste vormistamise vahend.

Keeled on alati laenanud vormivahendeid ja saanud mõjutusi nende kasutamisel. Siin analüüsitud tekstid erinevad oma suhetelt kontaktkeeltega. Vana kirjakeele tekstid on mõjutatud saksa keelest. Netitekstides on viidatud inglise keele mõjule, eriti spontaanses argises netikeeles, kuigi täpseid uurimusi ei ole. Samal ajal võib oletada, et ilukirjandus- ja ajakirjandustekstid on võõrkeelte mõjust vabamad, sest keeletoimetamine taandab teadlikult võõrmõju. Analüüs kinnitab osalt võimalikke kontaktkeelte mõjusid.

Saksamõjuline inversioon on sage ainult vanimas vaimulikus kirjanduses ning seostub seal ennekõike retoorilise funktsiooni ja katekismuslike kinniskonstruktsioonidega. Juba XVIII sajandi õpetlikus kirjanduses taandub inversioon minimaalseks ja püsib sellisena ka XXI sajandil. Oletasime, et inversioon tõuseb uuesti esile netikeeles, kuid analüüs seda ei kinnita. Siinne materjal kinnitab pigem varasemat (Metslang 2010) järeldust, et saksa ega inglise keele mallid (inversioon, mille abil vormistatakse ennekõike infosoove) ei pääse eesti keele üldküsimuse vormistuses esile.

Inglise keeles on kinnitust ootava küsimuse vormistamiseks kasutusel erinevad lauselõpulised küsijätkud, eesti keeles on nende kasutus marginaalne ning põhiosa neist esineb netikeeles. Kuigi esinemiskordi on väga 
vähe, võib siin ehk oletada inglise keele mõju suurenemist. Küsijätkude kasutamist võib toetada omakeelne lõpupartikkel või.

\section{Lühendid}

AJA - ajakirjandustekstid; DIA - dialoogitekstid; ILU - ilukirjandustekstid; KOMM - netikommentaarid; UT - uus testament

\section{Kirjandus}

Dingemanse jt 2014 = Mark Dingemanse, Joe Blythe, Tyko Dirksmeyer. Formats for other-initiation of repair across languages: An exercise in pragmatic typology. - Studies in Language 38 (1), 5-43.

Enfield jt 2010 = Nick J. Enfield, Tanya Stivers, Stephen Levinson. Questionresponse sequences in conversation across ten languages: An introduction. - Journal of Pragmatics 42 (10), 2615-2619. http://dx.doi. org/10.1016/j.pragma.2010.04.001.

Englert, Christina 2010. Questions and responses in Dutch conversations. Journal of Pragmatics 42, 2666-2684. http://dx.doi.org/10.1016/j. pragma.2010.04.005.

Erelt, Mati 2006. Lause õigekeelsus. Juhatused ja harjutused. Tartu.

Heinemann, Trine 2010. The question-response system of Danish. - Journal of Pragmatics 42, 2703-2725. http://dx.doi.org/10.1016/j. pragma.2010.04.007.

Hennoste jt 2013 = Tiit Hennoste, Andriela Rääbis, Kirsi Laanesoo. Küsimused eestikeelses infodialoogis II. Küsimused ja tegevused. - Keel ja Kirjandus $1,7-28$.

Heritage, John 2012. Epistemics in action: Action formation and territories of knowledge. - Research on Language \& Social Interaction 45 (1), 1-29.

Hyland, Ken 2002. What do they mean? Questions in academic writing. - Text \& Talk 22 (4), 529-557.

Laanesoo, Kirsi 2012. Pööratud polaarsusega retoorilised küsimused argivestluses. - Keel ja Kirjandus 7, 499-517.

Lindström, Liina 2016. Infostruktuur. - Eesti keele süntaks. Toim. Mati Erelt, Helle Metslang. (= Eesti keele varamu 3.) Tartu: Tartu Ülikooli kirjastus. (Ilmumas.)

Marley, Carol 2002. Popping the question: questions and modality in written dating advertisements. - Discourse Studies 4 (1), 75-98.

Metslang, Helle 1981. Küsilause eesti keeles. Tallinn: ENSV TA Keele ja Kirjanduse Instituut. 
Metslang, Helle 2010. Isepäine üldküsilause. - Emakeele Seltsi aastaraamat 55 (2009). Peatoim. Mati Erelt. Tallinn: Teaduste Akadeemia Kirjastus, $119-137$.

Metslang jt 2011 = Helle Metslang, Külli Habicht, Karl Pajusalu. Developmental paths of interrogative particles: the case of Estonian. - Folia Linguistica Historica 32, 149-187.

Metslang jt 2014 = Helle Metslang, Karl Pajusalu, Külli Habicht. Koordinatiivsed partiklid lause perifeerias. - Emakeele Seltsi aastaraamat 59 (2013). Peatoim. Mati Erelt. Tallinn: Teaduste Akadeemia Kirjastus, 139-161. http://dx.doi.org/10.3176/esa59.07.

Metslang jt 2015 = Helle Metslang, Karl Pajusalu, Külli Habicht. Conjunctive markers of polar questions in Estonian. - New Trends in Nordic and General Linguistics. Eds. Martin Hilpert, Jan-Ola Östman, Christine Mertzlufft, Michael Rießler, Janet Duke. Berlin, Munich \& Boston: De Gruyter, 283-306. http://dx.doi.org/10.1515/9783110346978.283.

Miestamo, Matti 2011. Polar interrogatives in Uralic languages. A typological perspective. - Linguistica Uralica XLVII (1), 1-21.

Quirk jt 1985 = Randolph Quirk, Sidney Greenbaum, Geoffrey Leech, Jan Svartvik. A Comprehensive Grammar of the English Language. London: Longman.

Reese, Brian Jon 2007. Bias in Questions. The University of Texas at Austin.

Romero, Maribel, Chung-hye Han 2004. On negative yes/no questions. Linguistics and Philosophy 27 (5), 609-658. http://dx.doi.org/10.1023/ B:LING.0000033850.15705.94.

Rumm, Andra 2015. Avatud küsimused suulises argivestluses. Magistritöö. http://dspace.ut.ee/bitstream/handle/10062/46889/Rumm_2015.pdf. (12.03.2016)

Saari, Henn 1976. Keelehääling. Tallinn: Valgus.

Schegloff, Emanuel A. 2007. Sequence Organization in Interaction. A Primer in Conversation Analysis. Cambridge: Cambridge University Press. http:// dx.doi.org/10.1017/CBO9780511791208.

Sepamaa, Henrik 1978. Pisut kas-küsimusest. - Keel ja Kirjandus 5, 300.

Stivers, Tanya 2010. An overview of the question-response system in American English conversation. - Journal of Pragmatics 42, 2772-2781. http:// dx.doi.org/10.1016/j.pragma.2010.04.011.

Stivers, Tanya, Nick J. Enfield 2010. A coding scheme for question-response sequences in conversation. - Journal of Pragmatics 42, 2620-2626.

\section{Korpused}

Eesti keele koondkorpus. http://www.cl.ut.ee/korpused/segakorpus/ (25.03.2015). Vana kirjakeele korpus. http://www.murre.ut.ee/vakkur/Korpused/ (25.03.2015). 


\title{
Forms and functions of polar questions across four centuries and six text types
}

\author{
TIIT HENNOSTE, HELLE METSLANG, \\ KÜLLI HABICHT, ANNI JÜRINE, \\ KIRSI LAANESOO, DAVID OGREN
}

The article deals with the various forms and functions of polar questions in written Estonian, as well as the relationships between form, function and text type. The analysis is based on material from 17th and 18th-century religious and didactic texts, modern fiction and journalistic texts, internet comment sections and Instant Messaging dialogues. 100 questions from each text type were used in the study. We divide the means of forming polar questions into primary (question markers and word order) and secondary (question-marking conjunctions and epistemic modal particles) means, as well as declarative sentences with question marks.

The main ways of forming polar questions are sentence-initial question particles (chiefly kas) and declarative sentences or questions featuring only secondary question markers. Each of these groups accounts for $27 \%$ of all questions. Sentence-final markers are common only in online dialogues, and inversion appears frequently only in old religious texts. Polar question markers and their usage differ between old and modern texts. Verbal markers have moved from the beginning of the sentence to the end, and the proportion of questions formed by secondary question markers has increased.

The primary function of polar questions in all text types except for old religious literature is to ask for confirmation of one's understanding (questions expressing assumptions or doubts); this function accounts for $56-75 \%$ of all questions. The proportion of information-seeking questions is $31-32 \%$ in fiction and journalistic texts and between $0-14 \%$ in other text types. Moreover, all text types featured examples of directives and rhetorical questions, and old religious texts featured "testing" questions (where the questioner knows the answer and is testing the conversation partner's knowledge).

In modern texts, requests for information are expressed primarily by sentenceinitial particles and word order. Information-seeking questions did not appear in older texts. Questions expressing doubt were formed in all printed texts by markers similar to those used to request for information; in internet texts, the usage of different markers was more variable. 
Questions expressing assumptions are in modern texts expressed primarily by declarative sentences and secondary markers, as well as sentence-final question markers in internet texts. In old written texts, such questions are formed by sentence-initial particles, which are often accompanied by secondary markers. Overall, secondary markers are closely associated with questions expressing assumptions, but are hardly ever found in information-seeking questions. The analysis reveals that the primary function of polar questions and the relationships between form and function do not depend on the time period, text type, or the reality/fictionality of the interaction. The preferences for particular means of question formation were not affected by prescriptive norms or language contact.

Keywords: written language, polar questions, functions of questions, registers, Estonian language

Tiit Hennoste

eesti ja üldkeeleteaduse instituut

Tartu Ülikool

Jakobi 2

51014 Tartu

tiit.hennoste@ut.ee

Helle Metslang eesti ja üldkeeleteaduse instituut

Tartu Ülikool

Jakobi 2

51014 Tartu

helle.metslang@ut.ee

Külli Habicht

eesti ja üldkeeleteaduse instituut

Tartu Ülikool

Jakobi 2

51014 Tartu

kulli.habicht@ut.ee 
Anni Jürine

maailma keelte ja kultuuride kolledž

Tartu Ülikool

Lossi 3

51003 Tartu

anni.jurine@ut.ee

Kirsi Laanesoo

eesti ja üldkeeleteaduse instituut

Tartu Ülikool

Jakobi 2

51014 Tartu

kirsi.laanesoo@ut.ee

David Ogren

eesti ja üldkeeleteaduse instituut

Tartu Ülikool

Jakobi 2

51014 Tartu

ogren@ut.ee 


\section{Lisad}

Tabel 3. Üldküsimuse vormivahendid tekstiliigiti

\begin{tabular}{|c|c|c|}
\hline & & Vaimulik \\
\hline \multirow{6}{*}{$\begin{array}{l}\text { Ainult üks pri- } \\
\text { maarne vormi- } \\
\text { vahend }\end{array}$} & Küsipartikkel lause alguses & 37 \\
\hline & Küsipartikkel lause lõpus & \\
\hline & Küsijätk lause lõpus & \\
\hline & Inversioon & 24 \\
\hline & Verb lause alguses & \\
\hline & Verb lause lõpus & \\
\hline \multirow{7}{*}{$\begin{array}{l}\text { Kahe primaarse } \\
\text { vormivahendi } \\
\text { kombinatsioon }\end{array}$} & Marker lause alguses + lause lõpus & \\
\hline & Marker lause alguses + lause lõpus + verb lõpus & \\
\hline & Marker lause alguses + inversioon & 1 \\
\hline & Marker lause alguses + verb algusmarkeri järel & 7 \\
\hline & Marker lause alguses + verb lause lõpus & \\
\hline & Partikkel lause lõpus + verb lause alguses & \\
\hline & Küsijätk lause lõpus + verb lause alguses & \\
\hline \multirow{3}{*}{$\begin{array}{l}\text { Primaarne ja } \\
\text { sekundaarne } \\
\text { vormivahend }\end{array}$} & Primaarne marker + sekundaarne vahend & 14 \\
\hline & Sõnajärg + sekundaarne vahend & 6 \\
\hline & Primaarne marker + sõnajärg + sekundaarne vahend & \\
\hline \multirow{3}{*}{$\begin{array}{l}\text { Ainult sekundaar- } \\
\text { sed vormivahendid }\end{array}$} & Episteemiline üldlaiend & \\
\hline & Sidesõna & 2 \\
\hline & Mitu sekundaarset vahendit & \\
\hline \multirow[t]{2}{*}{ Väitlause } & & 9 \\
\hline & Kokku & 100 \\
\hline
\end{tabular}

Tabel 4. Üldküsimuse funktsioonid tekstiliigiti

\begin{tabular}{|l|r|c|c|}
\hline & Vaimulik & Õpetlik & Ajakirjandus \\
\hline Infosoov & & & 31 \\
\hline Oletusküsimus & & 20 & 37 \\
\hline Kahtlusküsimus & 27 & 53 & 25 \\
\hline Retooriline küsimus & 49 & 21 & 4 \\
\hline Direktiiv & 0 & 6 & 3 \\
\hline Kooliküsimus oletusküsimusena & 15 & & \\
\hline Kooliküsimus infosoovina & 9 & & \\
\hline Kokku & 100 & 100 & 100 \\
\hline
\end{tabular}




\begin{tabular}{|c|c|c|c|c|c|}
\hline Õpetlik & Ajakirjandus & Ilukirjandus & $\begin{array}{c}\text { Neti- } \\
\text { kommentaar }\end{array}$ & Netidialoog & Kokku \\
\hline 48 & 35 & 14 & 16 & 14 & 164 \\
\hline & & 1 & 2 & 14 & 17 \\
\hline & & 2 & 2 & 4 & 8 \\
\hline 2 & 2 & 6 & & & 34 \\
\hline & 7 & 1 & 3 & 6 & 17 \\
\hline & & 1 & 2 & 4 & 7 \\
\hline & & 2 & 2 & 5 & 9 \\
\hline & & & 1 & & 1 \\
\hline & 1 & & & & 2 \\
\hline & 6 & 2 & 7 & 1 & 23 \\
\hline & 6 & 6 & 5 & 0 & 17 \\
\hline & & 1 & & 2 & 3 \\
\hline & & & 1 & 2 & 3 \\
\hline 31 & 7 & 8 & 9 & 13 & 82 \\
\hline 1 & 7 & 12 & 5 & 5 & 36 \\
\hline 5 & & 3 & 4 & 1 & 13 \\
\hline 3 & 6 & 8 & 7 & 7 & 31 \\
\hline 2 & 3 & 8 & 8 & 5 & 28 \\
\hline 3 & 1 & & & 4 & 8 \\
\hline 5 & 19 & 25 & 26 & 13 & 97 \\
\hline 100 & 100 & 100 & 100 & 100 & 600 \\
\hline
\end{tabular}

\begin{tabular}{|c|c|c|}
\hline Ilukirjandus & Netikommentaar & Netidialoog \\
\hline 32 & 12 & 14 \\
\hline 46 & 38 & 61 \\
\hline 19 & 28 & 14 \\
\hline 1 & 14 & \\
\hline 2 & 8 & 11 \\
\hline & & \\
\hline & & 100 \\
\hline 100 & 100 & \\
\hline
\end{tabular}

